\title{
Resiliensi Nafkah Rumah Tangga Pulau Kecil (Studi Kasus Pulau Wetar Kabupaten Maluku Barat Daya)
}

\author{
Household Livelihood Resilience In Small Island \\ (Case Study In Wetar Island, Southwest Maluku Regency)
}

*Junianita Fridianova Sopamena

\author{
Program Studi Penyuluhan Jurusan Sosial Ekonomi Pertanian, Unpatti Ambon, J1. Ir. M Putuhena Poka \\ Ambon - 97233
}

Received: 18 January 2019; Revised: 28 June 2019; Accepted: 1 July 2019

\begin{abstract}
ASBTRAK
Penelitian ini bertujuan untuk menganalisis resiliensi strategi nafkah rumah tangga Pulau kecil. Penelitian dilaksanakan pada bulan Maret sampai April 2019 di Kecamatan Wetar Utara Kabupaten Maluku Barat Daya, dengan tiga desa sampel yaitu Desa Uhak sebanyak 20 rumah tangga sampel, Desa Lurang sebanyak 30 rumah tangga sampel, dan Desa Noumatang dengan 20 rumah tangga sampel. Pemilihan sampel rumah tangga dilakukan secara sengaja, yaitu rumah tangga yang memanfaatkan usaha di darat dan laut sebagai basis utama sumber nafkah. Analisis data dilakukan secara deskriptif dengan tabulasi sederhana dan tabulasi silang untuk mempotret situasi dan kondisi wilayah studi. Hasil penelitian menunjukkan rumah tangga Pulau kecil cenderung memanfaatkan strategi nafkah on-farm dan off-farm sebanyak 44,3 persen rumah tangga, strategi nafkah on-farm dan non-farm sebanyak 28,6 persen rumah tangga, dan strategi on-farm dan non-farm sebanyak 27,1 persen rumah tangga. Pilihan strategi nafkah menempatkan rumah tangga yang tinggi resiliensi nafkahnya mencapai 51,4 persen, yang sedang resiliensi nafkahnya sebanyak 32,9 persen, dan rendah resiliensi nafkahnya hanya 15,7 persen. Secara umum dapat dikatakan rumah tangga Pulau kecil umumnya memiliki strategi nafkah yang resilien dalam menghadapi tantangan pemenuhan kebutuhan hidup.
\end{abstract}

Kata kunci: resiliensi; nafkah rumah tangga; pesisir; pulau kecil

\section{ABSTRACT}

The aim of this research is to analyze the resilience of livelihood strategies conducted by households in small island. Research was carried out from March to April 2019 in North Wetar District, Southwest Maluku Regency. Sample was contributed from three villages, respectively, Uhak Village with 20 households, Lurang Village with 30 households, and Noumatang Village with 20 households. Household sample was determined purposively and focused on household that exploits land and sea resources to be the main source of livelihood. Data analysis is conducted descriptively involving simple and cross tabulations that describe situations and conditions of research area. Result of research shows that households in small island are utilizing on-farm livelihood strategy by 44.3 percents of households,onfarm and off-farm livelihood strategy which is applied by 28.6 percents of households, and on-farm and non-farm livelihood strategy which is performed by 27.1 percents of households. The selection of livelihood strategy has affected livelihood resilience level. Livelihood strategy with the highest number of user has livelihood resilience level of 51.4 percents. Livelihood strategy with moderate number of user has livelihood resilience level of 32.9 persen. Livelihood strategy with the lowest number of user has livelihood resilience level of 15.7 percents. In general, it can be said that households in small island have resilient livelihood strategy in dealing with the challenges of life necessity fulfillment.

Keywords: resilience; household livelihood; coast; small island

\section{How to Cite:}

Sopamena, J. F. (2019). Resiliensi Nafkah Rumah Tangga Pulau Kecil ( Studi Kasus Pulau Wetar $\begin{array}{lllll}\text { Kabupaten Maluku Barat Daya ). HABITAT, 30(2), 79-87. } & \text {. }\end{array}$ https://doi.org/10.21776/ub.habitat.2019.030.2.10 


\section{Pendahuluan}

Masyarakat pulau kecil, senantiasa menyesuaikan aktivitasnya dengan situasi dan kondisi lingkungannya. Semua upaya pemenuhan kebutuhannya, sangat bergantung dari ketersediaan sumber-sumber nafkah dilingkungannya. Upaya pemenuhan kebutuhan, akan mengalami pasang surut sebagaimana dinamika situasi dan kondisi lingkungan masingmasing. Semakin mampu masyarakat memelihara lingkungan, maka semakin mungkin lingkungan menyediakan sumber-sumber nafkah yang dapat dimanfaatkan. Oleh karena itu, masyarakat cenderung memanfaatkan lingkungan secara arif untuk keberlanjutan pemenuhan kebutuhannya.

Dinamika sumber nafkah menyebabkan munculnya konsep dinamika nafkah rumah tangga. Namun, dalam upaya mempertahankan kehidupannya maka masyarakat akan berusaha mempertahankan sumber nafkah yang tetap dan berkelanjutan. Artinya, walaupun mengalami pasang surut, ada saja sumber nafkah yang dapat dimanfaatkan saat berada dalam kondisi kesulitan hidup.

Secara umum, pemanfaatan lingkungan sebagai sumber nafkah akan dibatasi oleh dinamika iklim yang berlangsung di pulau kecil. Masyarakat pulau kecil memiliki mekanisme tersendiri dalam menyikapi dinamika perubahan iklim. Biasanya pemanfaatan dua sisi darat dan laut, menjadi pilihan dalam memanfaatkan lingkungan sebagai sumber nafkah. Hal itulah yang menunjukkan masyarakat Pulau Kecil resilien dalam menjalankan strategi nafkah melalui pemanfaatan beragam sumber nafkah di lingkungannya.

Data (BPS, 2017; BPS, 2018) menunjukkan bahwa aktivitas masyarakat sepenuhnya bergantung pada pertanian secara luas, termasuk peternakan dan perikanan. Selain mengandalkan komoditas perkebunan (kelapa dan jambu mete), masyarakat juga mengusahakan ternak (didominasi babi dan ayam), serta usaha perikanan (perahu tanpa motor, perahu motor temple, dan kapal motor). Data ini paling tidak memberikan gambaran pemanfaatan sumber nafkah oleh rumah tangga pesisir Pulau Kecil, yang senantiasa bermain di dua area (darat dan laut). Namun untuk Pulau Wetar, belum ada data yang menunjukkan sumbangan beragam aktivitas

${ }^{*}$ Penulis Korespondensi.

E-mail: junianitasopamena@gmail.com tersebut terhadap penerimaan rumah tangga pesisir. Informasi penerimaan rumah tangga, menjadi acuan untuk mengembangkan usaha peningkatan kesejahteraan masyarakat pesisir di Pulau Kecil.

Studi-studi terkini di wilayah continental (Pulau Besar) menunjukkan masyarakat memanfaatkan beragam sumber nafkah supaya strategi nafkahnya tetap dalam resilien dalam memenuhi kebutuhan hidup. Hasil penellitian (Widodo, 2011) menjelaskan bahwa strategi nafkah berkelanjutan bagi rumah tangga miskin di daerah pesisir antara lain strategi nafkah sosial atau strategi ikatan sosial, strategi ini memanfaatkan ikatan sosial seperti kekerabatan, pertetanggan maupun perteman. Strategi ini memunkinkan masyarakat pesisir untuk berhutang. Rasa saling percaya dan mempercayai antar warga cukup tinggi, sehingga proses hutang piutang dapat berlangsung dengan lancar. Namun, apabila sekali saja terdapat pelanggaran maka rasa kepercayaan tersebut akan sangat cepat hilang sehingga masyarakat pesisir sangat berhati-hati dalam menjaga hubungan ini. (Fridayanti dan Dharmawan, 2013) menggolongkan strategi nafkah rumah tangga petani atas empat yaitu: intensifikasi strategi pertanian dengan memanfaatkan sektor pertanian secara efektif dan efisien, extensifikasi strategi non pertanian memanfaatkan sektor non pertanian dengan lebih efektif dan efisien melalui penerapan beragam pekerjaan di luar sektor pertanian, diversifikasi nafkah menerapkan keanekaragaman pola nafkah dengan cara mencari pekerjaan lain selain pertanian untuk menambah pendapatan, atau dengan mengerahkan tenaga kerja keluarga, dan rekayasa spasial (migrasi) usaha mobilitas ke daerah lain di luar desanya, baik secara permanen maupun sirkuler untuk memperoleh pendapatan. (Wahyono, $d k k$ 2014) menjelaskan bahwa membahas resiliensi masyarakat nelayan dilihat dari resiliensi tingkat individu yang dilihat dari tiga indikator yaitu, akses pada sumber daya, keragaman sumber pendapatan, dan status sosial individu. Ketiga indikator ini juga berpengaruh terhadap responden dikarenakan responden memiliki akses sumber daya berupa hasil dari wilayah pesisir dan wilayah darat.

(Sugiharto dkk,2016) menunjukkan bahwa, sebagian besar keluarga petani menjalankan strategi nafkah campuran. Hasil penelitian menunjukkan bahwa usia suami yang lebih muda, peningkatan pengeluaran per kapita, dan 
peningkatan modal fisik keluarga memengaruhi secara langsung kesejahteraan keluarga namun jenis strategi koping dan juga lokasi tidak memengaruhi kesejahteraan keluarga. Demikian pula hasil studi (Budiyanti dan Dharmawan, 2018) menjelaskan bahwa, rumah tangga di pesisir dominan memanfaatkan modal alam dan modal finansial dalam memenuhi kebutuhan sehari-harinya ataupun membantunya dalam keadaan krisis.

Sementara beberapa studi di Pulau Kecil juga cenderung menunjukkan hasil yang mirip dengan beberapa variasi dalam sumber nafkah. Selaitu itu, terdapat beberapa studi strategi nafkah yang dilakukan dalam konteks pulau kecil dengan hasilnya bahwa petani di pesisir cenderung berperan juga sebagai nelayan sesuai kondisi iklim yang berlangsung. Pertukaran peran antara petani dan nelayan, menunjukkan bahwa, aktivitas di pulau kecil terutama di pesisir sulit dipilah menjadi petani atau nelayan. Oleh karena itu, sering disebut petani sekaligus nelayan, dalam konteks laut - pulau di pulau kecil.(Subair dkk, 2014), (Pattiselanno dkk, 2017), (Sopamena dan Pattiselanno, 2018), maupun (Pattiselanno dkk, 2018) menjelaskan bahwa, petani di pulaupulau kecil cenderung melakukan strategi nafkah kolaborasi dengan memanfaatkan pertukaran peran antara petani dan nelayan dengan iklim sebagai faktor yang mendorong penyesuaian peran. Masyarakat pesisir Pulau Kecil memiliki tiga strategi penting dalam memenuhi nafkah rumah tangga, yaitu dengan mengembangkan potensi sumberdaya alam pertanian melalui menambah jumlah komoditas yang diusahakan dan berpotensi memenuhi kebutuhan sehari-hari; mengembangkan potensi sumberdaya alam pertanian dalam arti luas melalui upaya mengembangkan potensi pesisir sebagai tempat mencari ikan menggunakan pancing, panah, maupun jaring; dan mengembangkan potensi sumberdaya manusia melalui pengembangan usaha di luar pertanian sesuai keterampilan yang dimilikinya sebagai tukang. Penelitian tersebut juga menyimpulkan, bahwa kekeluargaan adalah basis paling berpengaruh yang mendasari kegiatan ekonomi masyarakat di pulau-pulau kecil.

Berdasarkan berbagai hasil penelitiaan sebelumnya dan data terkini di wilayah studi maka penelitian ini bertujuan untuk menganalisis resiliensi strategi nafkah rumah tangga di Pulau Kecil.

\section{Metode Penelitian}

\subsection{Waktu, Lokasi Penelitian, dan Metode Sampling}

Penelitian dilakukan di Kecamatan Kecamatan Wetar Utara Kabupaten Maluku Barat Daya Propinsi Maluku dengan Desa Uhak, Desa Lurang, dan Desa Noumatang sebagai Desasampel. Pemilihan Desa sampel ditentukan secara sengaja, karena keberadaan aktivitas darat-laut dalam konteks pertanian mendominasi sumber nakfah rumah tangga. Masyarakat di ketiga Desa melakukan kegiatan yang didominasi oleh usaha pertanian secara umum, walaupun kegiatan ini juga diselingi kegiatan nonpertanian. Penelitian dilakukan selama satu bulan, yaitu bulan Maret sampai April 2019. Penentuan sampel di ketiga Desa dilakukan secara sengaja (purposive) yaitu, keberadaan rumah tangga yang rutin melakukan aktivitas di darat dan di laut dalam pemenuhan kebutuhan rumah tangga. Desa Uhak dan Noumatang masing-masing 20 rumah tangga, sedangkan Desa Lurang dengan 30 rumah tangga sehingga total sampel 70 rumah tangga. Selain itu, dipilih juga informan kunci dari masing-masing Desa yaitu Pedagang Pengumpul Desa untuk mengeksplorasi jawaban responden. Informan kunci dipilih dengan dasar adanya ikatan yang dilakukan dengan petani dan atau nelayan di setiap Desa sampel.

\subsection{Metode Pengumpulan Data dan Analisis Data}

Data primer dikumpulkan dengan kuesioner yang diberikan kepada responden (Babbie, 2004) dan wawancara mendalam dengan informan kunci (Debus \& Novelli, 1996). Data sekunder diperoleh dengan observasi partisipatif (Robert \& Lincoln, 1994) serta (Babbie, 2004) di mana penulis harus terlibat langsung ke dalam kehidupan sehari-hari masyarakat dengan mendengar dan membedakan apa yang oleh masyarakat sebagai subjek penelitian telah katakan dan lakukan. Analisis data menggunakan Tabulasi Sederhana untuk menggambarkan kondisi dan karakteristik lokasi penelitian. Data yang diproses ditampilkan ke dalam tabel dan diagram untuk memudahkan pemaparan kondisi lokasi penelitian.

\section{Hasil dan Pembahasan}

\subsection{Karakteristik Responden}

3.1.1. Umur

Available online at HABITAT website: http://www.habitat.ub.ac.id ISSN: 0853-5167 (p); 2338-2007 (e) 
Tabel 1. menunjukkan sebagian besar responden memiliki umur yang tergolong muda. Semakin muda umur, berarti semakin mampu melakukan berbagai usaha dalam memenuhi kebutuhan hidup rumah tangganya. Artinya, masyarakat yang berumur muda lebih mudah menjalankan beragam sumber nafkah sebagai wujud dinamika strategi nafkah yang dipilihnya.

Tabel 1. Karakteristik Responden Berdasarkan Umur di Lokasi Studi

\begin{tabular}{ccc}
\hline \multirow{2}{*}{ Umur } & \multicolumn{2}{c}{ Total } \\
\cline { 2 - 3 } & Jumlah & $\%$ \\
\hline $15-64$ & 46 & 65,1 \\
\hline$>64$ & 24 & 34,3 \\
\hline TOTAL & 70 & 100,0 \\
\hline
\end{tabular}

\subsubsection{Tingkat Pendidikan}

Tabel 2. Karakteristik Responden Berdarkan Tingkat Pendidikan Formal di Lokasi Studi

\begin{tabular}{ccc}
\hline \multirow{2}{*}{ Pendidikan Formal } & \multicolumn{2}{c}{ Total } \\
\cline { 2 - 3 } & Jumlah & $\%$ \\
\hline SD & 14 & 20,0 \\
\hline SLTP & 20 & 28,6 \\
\hline SLTA & 26 & 37,1 \\
\hline Perguruan Tinggi & 10 & 14,3 \\
\hline TOTAL & 70 & 100,0 \\
\hline
\end{tabular}

Tabel 2. menggambarkan tingkat pendidikan responden yang sebagian besar berada pada pendidikan menengah (SLTP dan SLTA). Tingkat pendidikan secara tidak langsung, berkaitan dengan kemampuan SDM dalam menjalankan usaha pemenuhan kebutuhan hidup. Tingkat pendidikan yang lebih tinggi, cenderung memiliki pengetahuan yang lebih dalam memilih usaha yang menguntungkan. Paling tidak, dengan pendidikan formal yang lebih baik, rumah tangga dapat mengembangkan usaha yang lebih mengutungkan dan berorientasi ke bisnis dibandingkan ke subsisten.

\subsubsection{Jenis Mata Pencaharian Utama}

Tabel 3. Mata Pencaharian Responden di Lokasi Studi

\begin{tabular}{ccc}
\hline Mata & \multicolumn{2}{c}{ Total } \\
\cline { 2 - 3 } Pencaharian & Jumlah & $\%$ \\
\hline Nelayan & 14 & 20,0 \\
\hline Petani & 46 & 65,7 \\
\hline Pedagang/Warungan & 10 & 14,3 \\
\hline TOTAL & 70 & 100 \\
\hline
\end{tabular}

Tabel 3. memberikan gambaran bahwa, pertanian dalam arti luas masih menjadi pilihan sebagian rumah tangga Pulau Kecil.Hal itu sebenanrnya bukan sesuatu yang baru, karena keberadaan aktivitas di darat - laut sebagai kombinasi sumber nafkah merupakan warisan yang sudah berlangsung turun temurun. Akibat dinamika iklim juga, maka rumah tangga melakukan aktivitas dan memilih sumber nafkah dengan iklim sebagai faktor pembatas. Iklim yang menjadi faktor pembatas terutama curah hujan dan kondisi gelombang laut. Rumah tangga yang dominan usahanya di darat, tetap memiliki aktivitas di laut saat menunggu panen komoditas perkebunan utama (kelapa dan jambu mete). Sementara, rumah tangga yang dominan di laut, tetap menjalankan usahatani terutama komoditas hortikultura (sayur-sayuran) yang berfungsi ganda sebagai pangan rumah tangga maupun dijual untuk memenuhi kebutuhan rumah tangga lainnya.

\subsubsection{Jumlah Anggota Keluarga}

Tabel 4. Jumlah Anggota Keluarga Per Responden di Lokasi Studi

\begin{tabular}{ccc}
\hline JAK & \multicolumn{2}{c}{ Total } \\
\cline { 2 - 3 } (orang/jiwa) & Jumlah & $\%$ \\
\hline$<2$ & 27 & 38,6 \\
\hline$>2$ & 43 & 61,4 \\
\hline TOTAL & 70 & 100,0 \\
\hline
\end{tabular}

Tabel 4. menunjukkan sebagian besar rumah tangga memiliki jumlah anggota keluarga yang tergolong besar. Jumlah anggota keluarga yang besar dapat dimanfaatkan sebagai tenaga kerja dalam keluarga yang tidak dibayar. Namun, di sisi lain dapat menjadi beban dalam rumah tangga, sehingga menjadi sumber besarnya kebutuhan rumah tangga. Oleh karena itu, rumah tangga dengan jumlah anggota keluarga yang besar sulit mendukung anak-anak yang telah menyelesaikan SLTA untuk melaknjutkan pendidikan ke Perguruan Tinggi. Mereka yang telah lulus SLTA, kemudian mengembangkan usahanya sendiri dan mempersiapkan diri untuk berumah tangga (menikah).

\subsubsection{Penerimaan Rumah Tangga}

Penerimaan rumah tangga merupakan hasil usaha yang diperoleh setiap rumah tangga, dari berbagai sumber nafkah yang dipilih. Penerimaan rumah tangga di lokasi penelitian dapat dilhat pada Tabel 5. 
Tabel 5. Penerimaan Rumah Tangga di Lokasi Studi

\begin{tabular}{ccc}
\hline Penerimaan Rumah & \multicolumn{2}{c}{ Total } \\
\cline { 2 - 3 } Tangga & Jumlah & $\%$ \\
\hline$\leq$ Rp. 2.250 .000 & 25 & 35,7 \\
\hline P Rp. 2.250 .000 & 45 & 64,3 \\
\hline TOTAL & 70 & 100 \\
\hline
\end{tabular}

Berdasarkan tabel di atas, dapat dilihat bahwa sebagian besar responden memiliki penerimaanlebih besar dari Rp2.250.000, dengan persentase sebesar 64,3 persen. Penerimaan rumah tangga responden, terbesar disumbangkan oleh komoditas perkebunan jambu mete (untuk responden yang bersandar pada strategi nafkah on-farm) dan ditunjang oleh komoditas kelapa yang diolah menjadi kopra.

\subsection{Resiliensi Nafkah Rumah tangga}

\subsubsection{Sumber Nafkah}

Sumber nafkah rumah tangga Pulau Kecil sangatlah beragam. Akibat ketergantungan rumah tangga terhadap alam, menyebabkan sebagian besar aktivitas pemenuhan kebutuhan rumah tangga cenderung memanfaatkan potensi sumberdaya alam di Desa. Pemanfaatan lahan sebagai pilihan utama pemenuhan kebutuhan, berkaitan dengan budaya berusaha komoditas perkebunan. Oleh karena itu, kelapa menjadi komoditas unggulan. Seiring dengan perkembangan, maka jambu mete kemudian diusahakan dan kelihatannya mulai menggeser kelapa.

Usaha pertanian lain seperti usahatani sayuran dan ternak ayam, baru digeluti masyarakat setelah berkembangnya program CSR yang dilakukan oleh Perusahaan tambang yang berada di sekitar Desa. Usaha tersebut baru berlangsung sekitar 2-3 tahun terakhir, dengan frekuensi dua kali pembelian oleh perusahaan dalam setahun. Usaha perikanan juga merupakan usaha warisan, sebagai bukti pemanfaatan sumberdaya alam sekitar Desa. Masyarakat pulau kecil lebih banyak menetap di pesisir, sehingga cenderung memanfaatkan wilayah pesisir untuk mencari ikan. Awalnya ikan yang ditangkap, dimanfaatkan sebagai sumber pangan rumah tangga dan sebagian kecil dijual untuk memenuhi kebutuhan rumah tangga lainnya. Sekarang ini, keberadaan perusahaan menyebabkan rumah tangga yang berprofesi utama sebagai nelayan cenderung menjual hasil tanggkapannya ke perusahaan. Pilihan sasaran penjualan cenderung berkaitan dengan harga yang lebih menguntungkan mereka. Tabel 6 menggambarkan sumber nafkah rumah tangga, kontribusinya terhadap penerimaan rumah tangga, dan arah pemanfaatannya.

Tabel 6. Penyebaran Sumber Penerimaan Rumah Tangga dan Pemanfaatannya

\begin{tabular}{|c|c|c|c|c|}
\hline No & Sektor & $\begin{array}{c}\text { Rata-rata } \\
\text { Penerimaan } \\
\text { (Rp / Bulan) } \\
\end{array}$ & $\begin{array}{c}\text { Kontribusi } \\
(\%)\end{array}$ & Arah Pemanfaatan \\
\hline 1 & Pertanian & & & \\
\hline A & Jambu Mete & 1.500 .000 & 25,9 & Pendidikan dan Kesehatan \\
\hline $\mathrm{B}$ & Kelapa & 700.000 & 12,1 & Pendidikan dan Kesehatan \\
\hline $\mathrm{C}$ & $\begin{array}{l}\text { Tanaman Pangan (sayur- } \\
\text { sayuran) }\end{array}$ & 800.000 & 13,8 & Pangan dan kebutuhan rumah tangga \\
\hline $\mathrm{D}$ & Ternak Ayam & 400.000 & 6,9 & Pangan dan kebutuhan rumah tangga \\
\hline \multirow[t]{2}{*}{$\mathrm{E}$} & Madu & 600.000 & 10,3 & Memperbaiki Rumah \\
\hline & Sub Total & 4.000 .000 & 69,0 & \\
\hline 2 & Perikanan & & & \\
\hline \multirow[t]{2}{*}{$\mathrm{A}$} & Ikan & 800.000 & 13,8 & Memperbaiki rumah \\
\hline & Sub Total & 800.000 & 13,8 & \\
\hline 3 & Jasa & & & \\
\hline $\mathrm{A}$ & Pedagang Ikan & 500.000 & 8,6 & Pangan dan kebutuhan rumah tangga \\
\hline \multirow[t]{3}{*}{$\mathrm{B}$} & Kios & 500.000 & 8,6 & Pangan dan kebutuhan rumah tangga \\
\hline & Sub Total & 1.000 .000 & 17,2 & \\
\hline & TOTAL & 5.800 .000 & $\mathbf{1 0 0 , 0 0}$ & \\
\hline Kecil & $\begin{array}{l}\text { Tabel } 6 \text { memberikan info } \\
\text { er-sumber nafkah rumah } \\
\text { Sektor pertanian masih } \\
\text { n menggantungkan komodit }\end{array}$ & $\begin{array}{l}\text { asi tentang } \\
\text { ngga Pulau } \\
\text { nendominasi } \\
\text { perkebunan }\end{array}$ & $\begin{array}{l}\text { (jambu m } \\
\text { (sayuran), } \\
\text { usaha mı } \\
\text { warisan }\end{array}$ & $\begin{array}{l}\text { ete dan kelapa) serta komoditas pangar } \\
\text { diikuti mencari madu lebah sebaga } \\
\text { usiman, dan beternak ayam. Sebaga } \\
\text { dari orangtua, kelapa menjadi tiang }\end{array}$ \\
\hline
\end{tabular}


penyangga ekonomi rumah tangga Pulau kecil. Proses pengolahan menjadi kopra selalu dilakukan, walaupun terkendala harga yang tidak memadai. Harga kopra di tingkat Desa berkisar Rp. $2.000-5.000$ rupiah. Petani kemudian mengembangkan usahatani jambu mete, yang diyakini cocok dengan kondisi wilayah (tanah dan iklim) setempat. Ternyata, komoditas jambu mete berkembang dengan baik, bahkan mampu menjadi penopang utama penerimaan rumah tangga menggeser komoditas kelapa. Harga jual komoditas jambu mete di Desa berkisar Rp. 40.000 - 60.000 per kilogram. Petani mampu memproduksi jambu mete dengan kisaran $30-50$ kilogram per panen, dengan rata-rata produksi 40 kilogram. Produksi jambu mete masih tergolong rendah, karena luasan usahanya masih berkisar 0,25 - 0,5 hektare. Ada juga beberapa petani yang sudah mengembangkan usahatani jambu mete mencapai satu hektare, namun belum berproduksi.

Rendahnya harga jual di tingkat petani, disebabkan tranportasi ke pasar perdagangan yang sulit. Kecamatan Wetar Utara merupakan Kecamatan pemekaran, yang kelembagaan ekonominya masih sangat terbatas. Ketiadaan lembaga ekonomi seperti Bank dan Koperasi, menyebabkan aksesibilitas permodalan petani juga terhambat. Umumnya mereka mennjual hasilnya ke sesama petani, yang hendak menjual komoditas jambu mete maupun kopra ke pasar perdagangan di Ilwaki (ibukota Kecamatan Wetar) dengan jarak sekitar dua jam perjalanan darat. Keterbatasan sarana transportasi, menyebabkan masyarakat cenderung menggunakan motor tempel ke Ilwaki. Kalaupun menyewa motor tempel, biayanya mencapai Rp. $400.000-500.000$ disesuaikan kondisi gelombang laut. Padahal harga kopra di Ilwaki dapat mencapai Rp. 8.000, sedangkan jambu mete mencapai Rp. $75.000-85.000$ per kilogramnya. Petani di Wetar Utara tentunya mengalami kerugian, namun Pemerintah
Kecamatan maupun Kabupaten MBD belum terlihat melakukan upaya yang dilakukan untuk melengkapi kekurangan sarana dan prasarana yang dimiliki Lurang sebagai Ibukota Kecamatan Wetar Utara. Padahal, di Kecamatan Wetar Utara terdapat Perusahaan Tambang Tembaga PT BPR yang sudah beroperasi sekitar lima tahun.

Kenyataan tersebut di atas sejalan dengan hasil penelitian (Sembiring 2014) yaitu livelihood asset yang dimiliki dan dimanfaatkan oleh rumah tangga petani baik di Dusun Klaces maupun Lempong Pucung memiliki hubungan dengan aktifitas nafkah yang mereka lakukan. Maupun hasil penelitian (Isabella dan Hendriani, 2010) yaitu, resiliensi keluarga cenderung merujuk pada proses coping yaitu tindakan yang dilakukan keluarga untuk mengatasi kesulitan dan adaptasi dalam keluarga.

\subsubsection{Strategi Nafkah Rumah Tangga}

Strategi nafkah yang dikembangkan petani di Kecamatan Wetar Utara Selatan dilakukan melalui tiga cara yaitu: mengembangkan usahataninya dengan komoditas selain kelapa seperti jambu mete, mengembangkan usahataninya dengan aktivitas pertanian dalam arti luas sebagai peternak dan nelayan, dan menekuni pekerjaan baru di luar pertanian seperti berdagang dan membuka usaha warung. Jelasnya terlihat pada Tabel 7.

Tabel 7. menguraikan strategi nafkah yang dikembangkan oleh rumah tangga Pulau Kecil terkategori atas tiga yaitu :
a. Mengembangkan komoditas unggulan selain kelapa (jambu mete), yang masuk ke strategi on-farm,
b. Mengembangkan aktivitas pertanian secara luas (beternak ayam dan menangkap ikan), yang masuk ke strategi non-farm,
c. Melakukan pekerjaan di luar pertanian (berdagang dan usaha warung), yang masuk strategi off-farm.

Tabel 7. Distribusi Responden Menurut Strategi Nafkah

\begin{tabular}{ccccccccc}
\hline \multirow{2}{*}{ Desa } & \multicolumn{7}{c}{ Strategi Nafkah } \\
\cline { 2 - 9 } & $\mathrm{A}$ & $\%$ & $\mathrm{~B}$ & $\%$ & $\mathrm{C}$ & $\%$ & Jumlah & $\%$ \\
\hline Uhak & 9 & 12,9 & 5 & 7,1 & 6 & 8,6 & 20 & 28,6 \\
\hline Lurang & 12 & 17,1 & 7 & 10,0 & 11 & 15,7 & 30 & 42,8 \\
\hline Noumatang & 10 & 14,3 & 7 & 10,0 & 3 & 4,3 & 20 & 28,6 \\
\hline Total & 31 & 44,3 & 19 & 27,1 & 20 & 28,6 & 70 & 100,0 \\
\hline
\end{tabular}

Keterangan :

A : On-farm dan Non Farm

B : On-farm dan Off-Farm

C : On-farm, Non-Farm, dan Off-Farm 
Strategi on-farm menjadi pilihan utama karena, ketersediaan lahan usaha yang dapat dikembangkan dengan komoditas jambu mete. Hampir sebagian besar rumah tangga (43,3 persen) memanfaatkan strategi ini. Komoditas jambu mete selain cocok diusahakan di Pulau Wetar, juga memiliki harga jual yang lebih baik ketimbang kopra. Komoditas jambu mete, juga secara budaya tidak berbeda jauh teknis usahanya dengan kelapa. Oleh karena itu, masyarakat lebih memilih megembangkan komoditas perkebunan, sesuai dengan budaya berusahatani komoditas perkebunan yang sudah berlangsung selama ini. Kenyataan tersebut sejalan dengan pandangan (Scoones, 1988) pada dua dari tiga bentuk strategi nafkah mulai dari intensifikasi dan ekstensifikasi (memperbanyak komoditas yang diusahakan) dan menerapkan pola nafkah ganda (sebagai nelayan dan tukang). Namun, mereka tidak menjalankan rekayasa spatial atau migrasi karena, keberadaan Kecamatan Wetar Utara masih rendah aksesibilitasnya ke luar Pulau. Jika merujuk pada (Ellis, 2000) maka, petani umumnya menjalankan strategi memanfaatkan modal sumberdaya alam (memanfaatkan lahan pertanian dan memanfaatakan pesisir untuk menangkap ikan), serta strategi memanfaatkan modal sumberdaya manusia (memanfaatkan kemampuan berdagang dan membuka usaha warung).

Ketiga pilihan tersebut, menunjukkan adanya dinamika strategi nakfah yang resilien oleh rumah tangga Pulau Kecil. Menurut (Speranza dkk, 2014), resiliensi mata pencaharian tergantung bagaimana fungsi mata pencaharian pada kapasitas dan agen, serta kondisi sosial, institusi, dan alam. Konsep resiliensi dapat membantu untuk memahami faktor-faktor yang memungkinkan masyarakat untuk melindungi mata pencahariannya dari konsekuensi buruk perubahan (perubahan iklim dan variabilitas iklim). Resiliensi strategi nafkah dilihat dari kemampuan masyarakat untuk melindungi dan mempertahankan mata pencahariannya. Jelasnya terlihat pada Tabel 8.

Kategori resiliensi strategi nafkah pada lokasi penelitian dibagi atas tiga kategori yaitu :

a. Tinggi (selalu memiliki alternatif dalam memenuhi kebutuhan dengan kemampuan rumah tangga sendiri),

b. Sedang (kadang-kadang memiliki alternatif dalam memenuhi kebutuhan dengan kemampuan rumah tangga sendiri), dan

c. Rendah (kurang memiliki alternatif dalam memenuhi kebutuhan dengan kemampuan rumah tangga sendiri).

Tabel 8. Resiliensi Strategi Nafkah Rumah Tangga Pulau Kecil

\begin{tabular}{ccccccccc}
\hline & \multicolumn{7}{c}{ ResiliensiStrategi Nafkah } \\
\cline { 2 - 10 } Desa & Tinggi & $(\%)$ & Sedang & $(\%)$ & Rendah & $(\%)$ & Jumlah & $(\%)$ \\
\hline Uhak & 10 & 14,3 & 6 & 8,6 & 4 & 5,7 & 20 & 28,6 \\
\hline Lurang & 15 & 21,4 & 10 & 14,3 & 5 & 7,1 & 30 & 42,8 \\
\hline Noumatang & 11 & 15,7 & 7 & 10,0 & 2 & 2,9 & 20 & 28,6 \\
\hline Total & 36 & 51,4 & 23 & 32,9 & 11 & 15,7 & 70 & 100,0 \\
\hline
\end{tabular}

Tabel 8 menunjukkan bahwa, sebagian besar rumah tangga Pulau kecil memiliki resiliensi yang tergolong tinggi. Hal ini ditunjukkan dengan kemampuan melakukan dinamisasi strategi nafkah, dari on-farm, offfarm, bahkan non-farm. Tonggak utama strategi nafkah yaitu on-farm, sebagai sumber pemenuhan kebutuhan yang jumlahnya besar seperti pendidikan anak dan kesehatan. Sementara strategi non-farm difokuskan pada pemenuhan pangan sehari-hari maupun kebutuhan rutin lainnya. Sedangkan strategi offfarm tidak dapat dilakukan oleh semua rumah tangga, karena membutuhkan keterampilan dalam mengelola usaha dagang maupun membuka usaha warung. Sesuai hasil penelitian (Marsevaa $\mathrm{dkk}, \quad 2016)$ yaitu, faktor-faktor yang memengaruhi tingkat resiliensi rumah tangga petani adalah tingkat pendidikan, tingkat pendapatan.

Resiliensi strategi nafkah yang terkategori sedang, menunjukkan rumah tangga masih bergantung pada kerabat atau saudara, bahkan juga ke orangtua dalam pemenuhan kebutuhannya. Umumnya dialami oleh rumah tangga mudah yang tergolong belum sepenuhnya mapan. Demikian pula dengan rumah tangga yang resiliensi strategi nafkahnya tergolong rendah, cenderung berada pada rumah tangga baru yang belum bekerja penuh dan sangat bergantung pada orangtuanya. Namun, setidaknya setiap rumah tangga memanfaatkan berbagai sumber nafkah dengan bersandar pada satu sumber nafkah utama dan didukung oleh 
sumber nafkah penunjang yang biasanya digunakan untuk memenuhi kebutuhan hidup sehari-hari. Hasil penelitian (Anugrahini, 2018), mengatakan bahwa resiliensi sosial yang dialami nelayan kamal muara dalam menghadapi dampak reklamasi di Jakarta tercermin dari tindakantindakan yang dilakukan para nelayan seperti tidak melaut pada saat air keruh, berbusa dan penuh lumpur, dan tindakan yang dilakukan untuk memenuhi kebutuhan hidup selama tidak melaut yaitu dengan cara mencari pinjaman, menjual sesuatu yang dimiliki nelayan. Berbeda dengan hasil penelitian tentang resiliensi dalam menghadapi bencana (Ariviyanti dan Pradoto, 2014), bahwa faktor-faktor yang meningkatkan resiliensi masyarakat dalam menghadapi bencana rob di Kelurahan Tanjung Emas Semarang yaitu, masyarakat pesisir disana mereka membuat peninggian rumah, peninggian jalan dan adanya organisasi sosial tanggap bencana.

\section{Kesimpulan}

Rumah tangga Pulau kecil cenderung memanfaatkan tiga strategi nafkah dengan bersandar pada satu sumber nafkah utama, yaitu : 1. Pengembangan komoditas per-kebunan (onfarm) yaitu mengusahakan komoditas jambu mete selain kelapa, sebagai sumber nafkah utama, 2. Strategi non-farm, yaitu menjalankan usaha ternak dan mennangkap ikan, dan 3. Strategi non-farm dengan melakukan usaha dagang dan warung. Pilihan strategi on-farm dan non-farm dilakukan oleh 44,3 persen rumah tangga. Strategi nafkahon-farn, non-farm, dan off-farm dilakukan oleh 28,6 persen rumah tangga. Sedangkan strateggi nafkahon-farm dan off-farm, dilakukan oleh 27,1 persen rumah tangga Pulau kecil.

Pilihan strategi nafkah menempatkan rumah tangga yang tinggi resiliensi nafkahnya mencapai 51,4 persen, yang sedang resiliensi nafkahnya sebanyak 32,9 persen, dan rendah resiliensi nafkahnya hanya 15,7 persen. Ketergantungan rumah tangga yang sedang dan rendah resiliensi nafkahnya, terutama diarahkan pada orangtua, kerabat, dan saudara karena merupakan rumah tangga yang belum mapan (berusia muda). Namun, kelompok rumah tangga tersebut tetap berupaya mengembangkan strategi nafkahnya menuju ke strategi nafkah yang resilien.

Pengembangan strategi nafkah di masyarakat menunjukkan pentingnya pemerintah dalam menunjang tercapainya strategi nafkah yang resilien. Artinya, pemerintah diharapkan membuka ruang pengembangan ekonomi masyarakat, yang ternyata mengalami kesulitan mengkakses lembaga keuangan dalam pengembangan usaha. Konkritnya, pemerintah diharpkan mendorong hadirnya Perbankan di Kecamatan Wetar Utara yang dapat menunjang pengembangan ekonomi masyarakat, memperlancar aktivitas ekonomi, serta mendukung perluasan usaha melalui pemanfaatan pinjaman modal Perbankan. Mengingat potensi pengembangan cukup memadai, namun tidak berarti apa-apa jika tidak tersedia kelembagaan ekonomi yang dapat diakses masyarakat.

\section{Ucapan Terimakasih}

Penelitian ini dapat terselenggara atas Surat Ijin Penelitian oleh Dekan Fakultas Pertanian Universitas Pattimura No. 674/UN13.1.5.1/AD/2019 tanggal 19 Maret 2019.

\section{Daftar Pustaka}

Anugrahini, T. (2018). Resiliensi Sosial Nelayan Kamal Muara Dalam Menghadapi Dampak Reklamasi Teluk Jakarta. Jurnal PKS.17.1 : $37-46$.

Ariviyanti, N. \& Pradoto, W. (2014). FaktorFaktor Yang Meningkatkan Resiliensi Masyarakat Dalam Menghadapi Bencana Rob Di Kelurahan Tanjung Emas Semarang. Jurnal Teknik. 3.4 : 991-1000.

Babbie, E. (2004). The practice of social research. CA : Thomson / Wadsworth: Publisher : Belmont.

BPS Kabupaten MBD.(2017). Kecamatan Wetar Utara Dalam Angka Tahun 2017. Tiakur : BPS Kabupaten MBD.

BPS Kabupaten MBD. (2018). Kecamatan Wetar Utara Dalam Angka Tahun 2018. Tiakur : BPS Kabupaten MBD.

Budiyanti, I., \& Dharmawan, A. H. (2018). Strategi Nafkah Dan Relasi Sosial Rumahtangga. Jurnal Sains Komunikasi dan Pengembangan Masyarakat [JSKPM], Vol. 2 (1), 105-122.

Debus, M., \& Novelli, P. (1996). Methodological Review: A Handbook for Excellence in Focus Group Research. Washington D.C: Academy for Educational Development. 
Ellis F. (2000). Rural Livelihood and Diversity in Development Countries. New York US: Oxford University Press.

Fridayanti, N.\& Dharmawan, A.H., (2013). Analisis Struktur dan Strategi Nafkah Rumahtangga Petani Sekitar Kawasan Hutan Konservasi di Desa Cipeuteuy, Kabupaten Sukabumi.Jurnal Sodality, Vol 01, No $01: 26-36$.

Isabella \& Hendriani, W. (2010). Resiliensi Pada Keluarga Yang Tinggal Di Lingkungan Lokalisasi Dupak, Bangunsari. Jurnal Insan, 12(03) : 176-186.

Marseva, A. D,.Putri, E. I. K,.\&Ismail, A., (2016). Analisis Faktor Resiliensi Rumah Tangga Petani dalam Menghadapi Variabilitas Iklim.JEPI Vol 17, No. 1 : 1527.

Pattiselanno, A. E., Tuhumury, M. T., Wenno, N. F., \& Sopamena, J. F. (2017). Collaborative Livelihood Strategy: A Reflection of Social Network in Economic Activity (Case Study in Small Islands, Maluku Province, Indonesian). International Journal of Environment, Agriculture and Biotechnology (IJEAB), Vol-2, Issue-5, 2466-2472.

Pattiselanno, A.E., E. Jambormias, \& Sopamena, J.F. (2018). Strategi Nafkah Petani Perkotaan Pulau Kecil (Studi Kasus Kecamatan Leitimur Selatan Kota Ambon). Jurnal Sosial Humaniora (JSH) [2018], Volume 11, Ed. 2 : 104-120.

Robert, D., \& Lincoln, J. (1994). Handbook of Qualitative Research. Thousand Oaks : Sage Publications.

Scoones, I., (1998). Sustainable Rural Livelihoods A Framework For Analysis. Paper 72; institute of Development Studies.

Sembiring, S.T., (2014). Resiliensi Nafkah Rumahtangga Petani Di Kawasan Rawan Bencana Rob Kecamatan Kampung Laut, Kabupaten Cilacap. Jurnal Sodality,Vol 08, No 01 : 33-46

Sopamena, J. F., \& Pattiselanno, A. E. (2018). Tnyafar: Women, Livelihoods Strategy in Selaru Island, West Southeast Maluku District. International Journal of Environment, Agriculture and
Biotechnology (IJEAB), Vol -3, Issue-5, 1685-1690.

Speranza, I. Matin, U. W. \& Stephen, R .(2014). An Indicator Framework for Assessing Livelihood Resilience in the Context of Social-ecological Dynamic.Global Enviromental Change. 28. pp. 109-119.

Subair, A., L.M. Kolopaking, S. Adiwibowo, \& MB Pranowo., (2014). Resiliensi Komunitas Dalam Merespon Perubahan Iklim Melalui Strategi Nafkah :Studi Kasus Desa Nelayan Di Pulau Ambon. Maluku. Jurnal Sosial Ekonomi Kelautan dan Perikanan, 9 (1) : 77-90.

Sugiharto, A. Hartoyo, \& Muflikhati, I. (2016). Strategi Nafkah Dan Kesejahteraan Keluarga Pada Keluarga Petani Tadah Hujan. Jur. Ilm. Kel. \&Kons., Vol. 9, No.1, $33-42$.

Wahyono, A. Imron, M. \& Nadzir.I., (2014). Resiliensi Komunitas Nelayan Dalam Menghadapi Perubahaan Iklim Kasus Di Desa Grajagan Pantai, Banyuwangi, Jawa Timur. Jurnal Masyarakat \& Budaya. 16.20 : 259-274.

Widodo, S., (2011). Strategi Nafkah Berkelanjutan Bagi Rumah Tangga Miskin Di Daerah Pesisir. Jurnal Makara Sosial Humaniora. 15.1 : 10-20. 